\title{
Comparative design procedures of stone columns for liquefaction stabilization
}

\author{
Messafer $\mathrm{T}^{1,}{ }^{*}$, Hassak $\mathrm{M}^{2}$, Abzar A ${ }^{2}$ \\ Research Unit: Materials, Processes and Environment, M'Hamed Bougara University of Boumerdes, Algeria \\ Civil Engineering Department, M’Hamed Bougara University, Boumerdes, Algeria, \\ Corresponding Author: tmessafer@hotmail.co.uk
}

Received: 17-11-2019

Accepted: 18-01-2020

\begin{abstract}
Soil liquefaction is one of the most important and complex phenomena of soil dynamics. It is a loss of résistance of loose granular soils under a seismic shock.

The aim of this work is to study the improvement made on a liquefiable soil using a stone column solution by several methods namely observational, static and dynamic solutions. The site used for this application is located in a terminal port container in Algiers. The analysis was carried out using the test results of standard penetration and cone penetrometer tests completed during a site investigation.

A comparative study between the methods was carried out to determine the most suitable method. The results of the 3 methods showed that the sizing by taking into account the earthquake, the mesh of stone columns is denser. It was deduced that it is important to analyze by the dynamic method in seismic zones and by static or observational techniques in areas of no or low risk of liquefaction. Recommendation for further research was put forward to develop new tools in order to improve current design methods.
\end{abstract}

Key words: Liquefaction, stone columns, Keller, dynamic, analysis, container terminal.

\section{Introduction}

Ports are works that are built to create zones of extension on the seas and rivers. Most of these are natural deposits of sand and gravels. This type of material is likely to liquefy because of its grain size and due to the high and variable hydraulic gradient depending on the mechanical and hydraulic load. These are already two favorable conditions for triggering the liquefaction phenomenon when a cyclic or monotonous solicitation manifests itself (Seed and Idriss, 1971).

Limited availability of adequate land for construction has prompted engineers to consider improvement techniques for strengthening weak soils. Techniques such as dynamic compaction, vibro-compaction, preloading, vibro replacement, compaction grouting, permeation and jet grouting have been used (Sarker and Abedin, 2015). Stone columns have had a proven record of success due to their easy use and economy. They have been used in many areas such as increasing the bearing capacity of soils, reducing settlement of structures, accelerating the rate of consolidation (Han and Ye, 2002) and to increase the resistance to liquefaction (Kumari et al, 2018).

The method of construction of stone columns consists of replacing the weak material with compacted granular material. This creates a flexible structure compared to concrete piles and allows the draining of groundwater and dissipation of water pressure and increasing the bearing capacity of the weak soils which improves the resistance to liquefaction (Babu et al, 2013). Several types of granular fill were studied (Samuel Thanaraj et al, 2019). The many applications of stone columns have allowed this solution to be chosen as a primary alternative to other mitigation measures.

Following the evolution of international trade at port level near Algiers, development work has begun with the construction of a container terminal. Earthworks comprised placing of a 
hydraulic embankment from Oued El-Harrach during the 1990s. This material was placed in a loose state.

An extensive program of laboratory and in situ tests indicated the fill needed stabilization prior to letting the site being used as a vital terminal port container. In particular in situ tests showed that the liquefaction potential was high and therefore improvement of the site with stone column method was analyzed. Several methods of designing a stone column solution were assessed and the more appropriate was recommended.

\section{Investigation Works}

The container terminal of the port of Algiers covers an area of almost 18 hectares, located west of the bay of Algiers and in the south-eastern part of Algiers port on the Mediterranean Sea.

Different boreholes and in situ tests (Figure 1) carried out on the site have revealed an anthropogenic soil, composed of a granular fill up to 12 meters thick, above marls and marly clay surmounted in places by a layer of fractured sandstone (Figure 2).

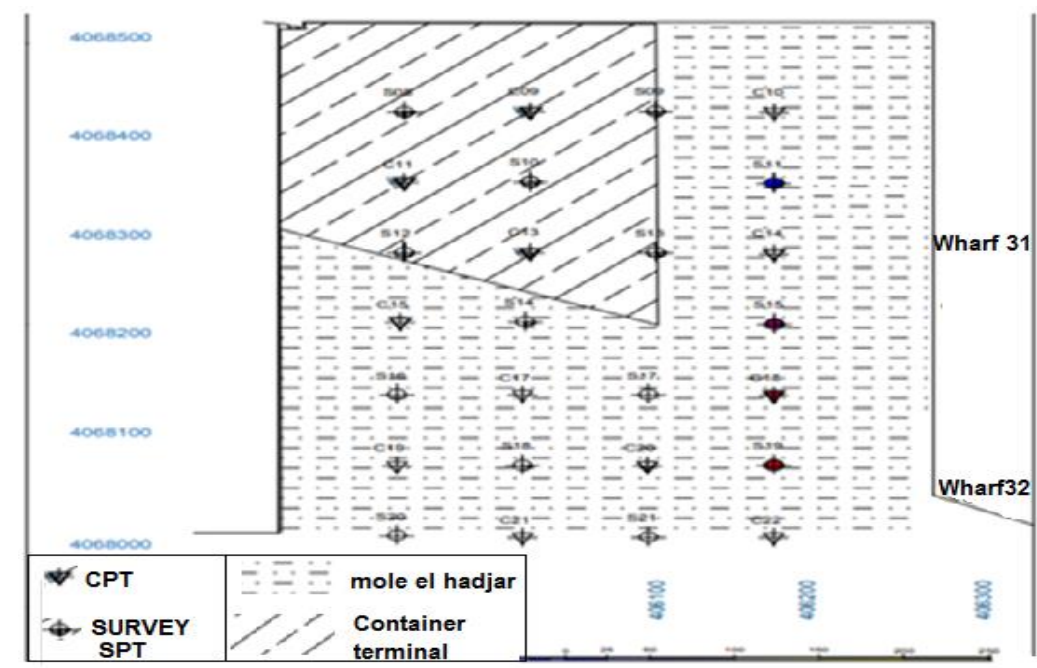

Fig. 1. Location of boreholes and field tests.

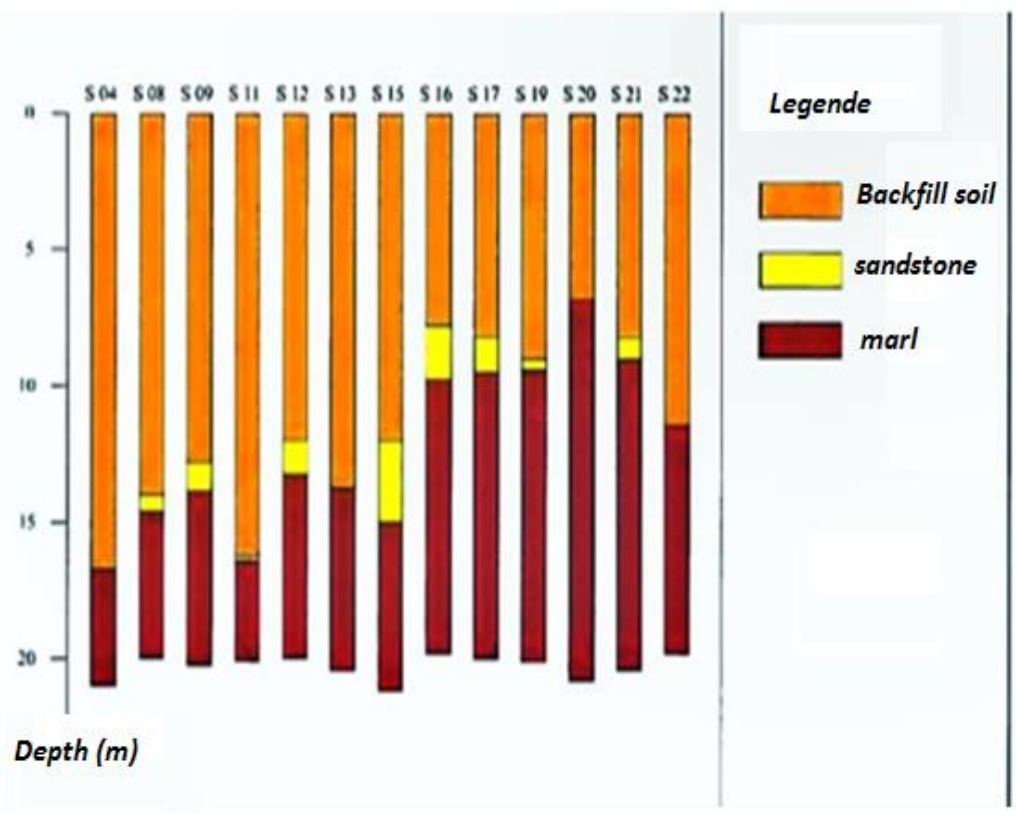

Fig. 2. Layers encountered on site 
Laboratory tests on samples of granular fill have shown that the amount of fine contents vary between 9 and 43\%. The grading curves are within the grading zones delimiting the area of most liquefiable soils (Faccioli and Resendiz, 1976).

\section{Mechanical characteristics of the anthropic soil}

Standard penetration (SPT) and static cone penetration tests (CPT) results carried out are plotted on Figures 3 and 4 below:

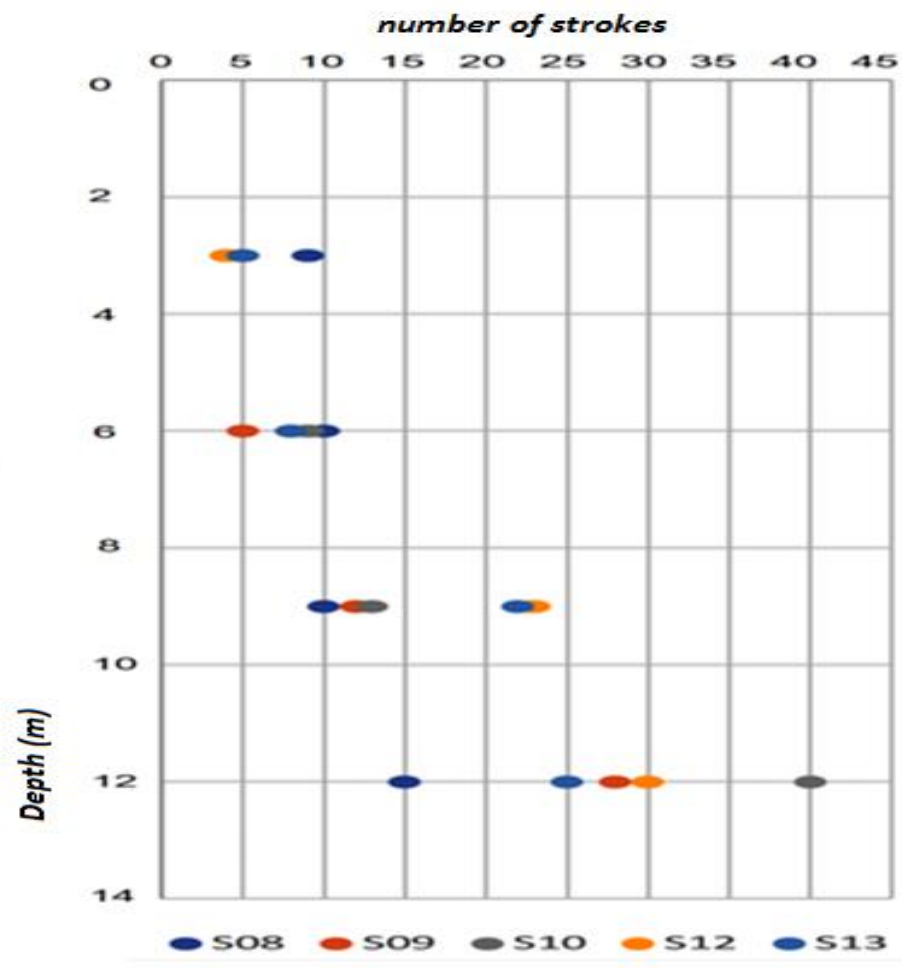

Fig. 3. SPT test results (anthropic soil)

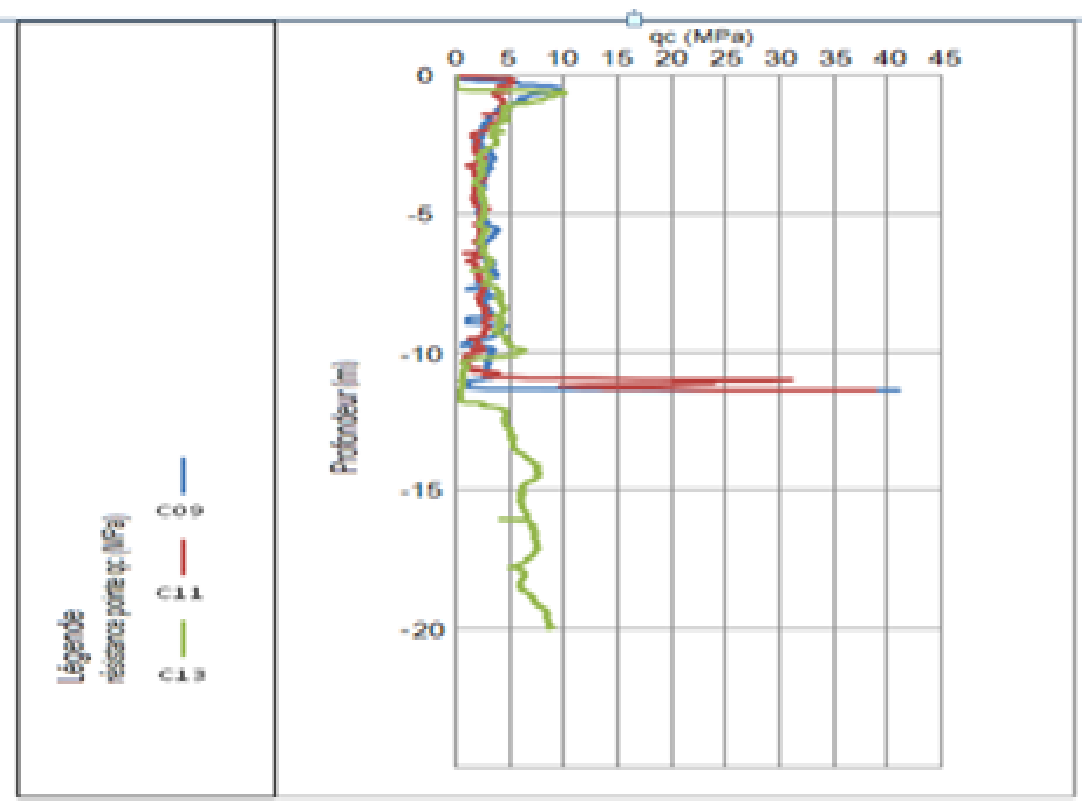

Fig. 4. CPT test results (anthropic soil)

The results show that the fill is in a loose state and the natural soil beneath the fill is denser. 


\section{Mechanical characteristic of the bedrock (Marl)}

SPT) and CPT results carried out are plotted on the bedrock are summarized on Figures 5 and 6 below:

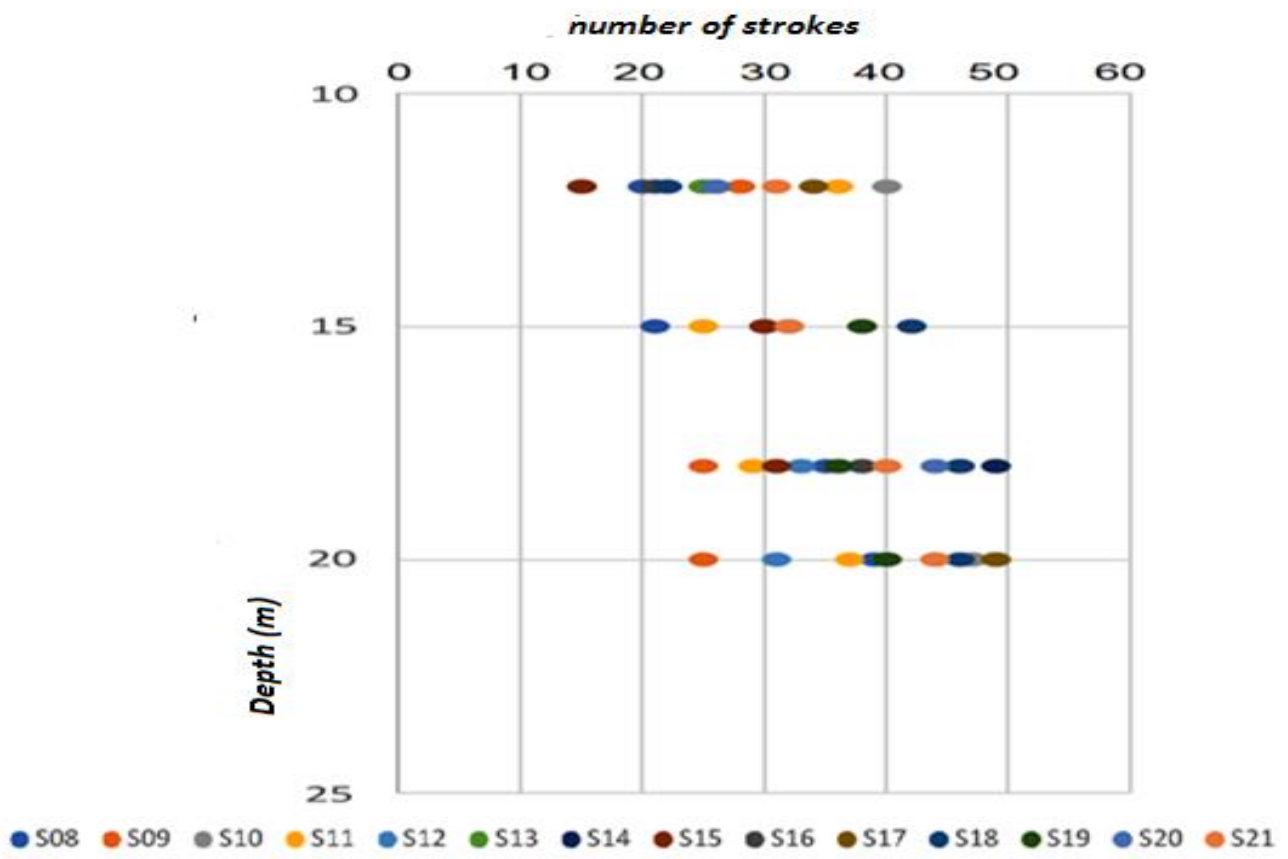

Fig. 5. SPT test results in the Marl layer

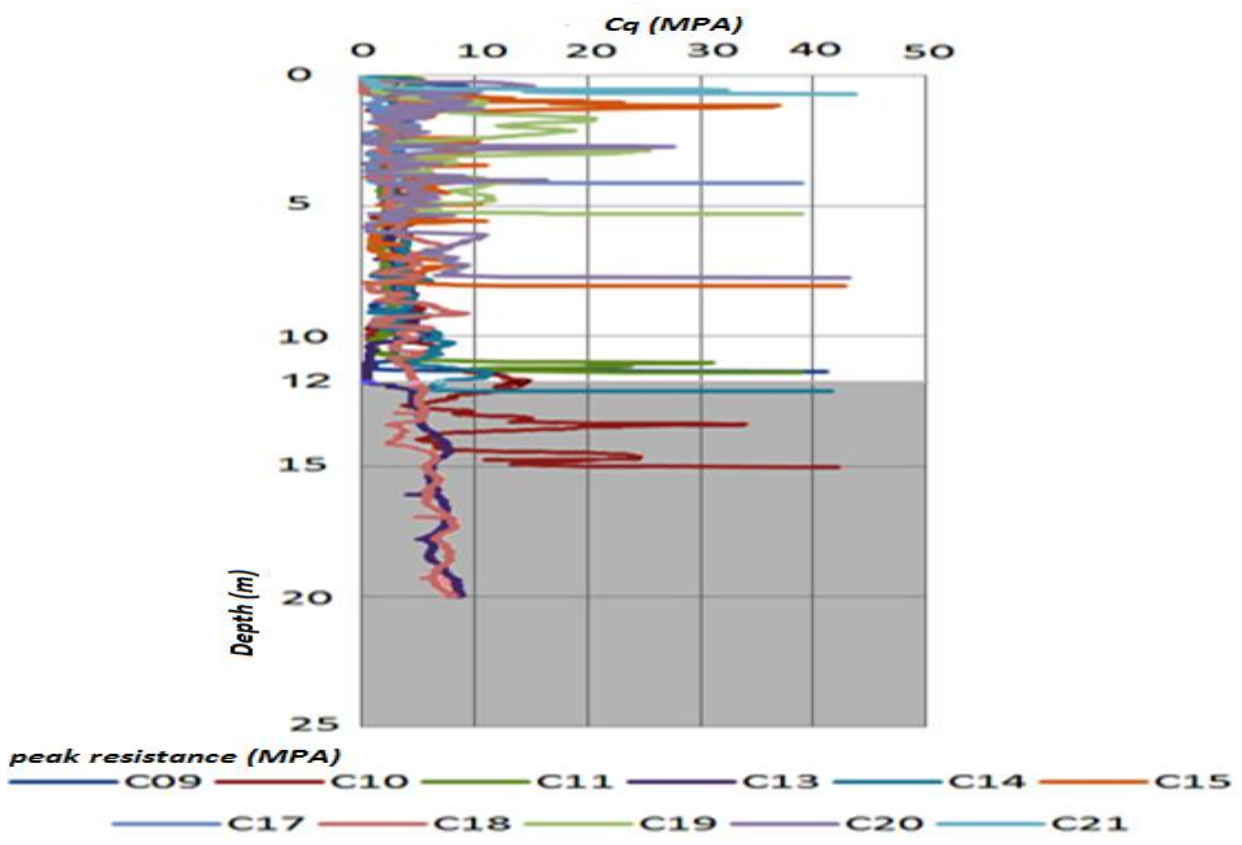

Fig. 6. CPT test results in the Marl layer

Analysis of the geotechnical properties obtained from the laboratory and in situ tests of the embankment material and the layer of marl make it possible to highlight the following points: 
- Embankment materiel is loose, compressible with low density. In addition the water table was detected at around $2.3 \mathrm{~m}$ depth.

- The marl layer located between 7.65 and $15 \mathrm{~m}$ depth has very good geotechnical characteristics

\section{Analysis of the liquefaction potential by empirical methods}

Liquefaction potential is assessed by comparing the rate of shear resistance (CRR) calculated for a site with the rate of shear stress (CSR) induced by the earthquake. The safety factor Fs being the ratio between CRR and CSR.

The empirical equation of Seed and Idriss (Seed and Idriss, 1971) is used to estimate CSR. The maximum acceleration is taken as $0.4 \mathrm{~g}$ according to the recommendations of the Algerian seismic regulation (RPA, 2003) and the coefficient Rd is determined by the expression of Blake (Blake, 1997).

\subsection{Analysis based on SPT tests}

The CRR indices were calculated by the method of Idriss and Boulanger (Idriss and Boulanger, 2006). The results obtained (Figure 7) show that the risk of liquefaction is high in the zone up to 10 to 12 meters in depth as the values of Fs are low and do not exceed the limit (1.25).

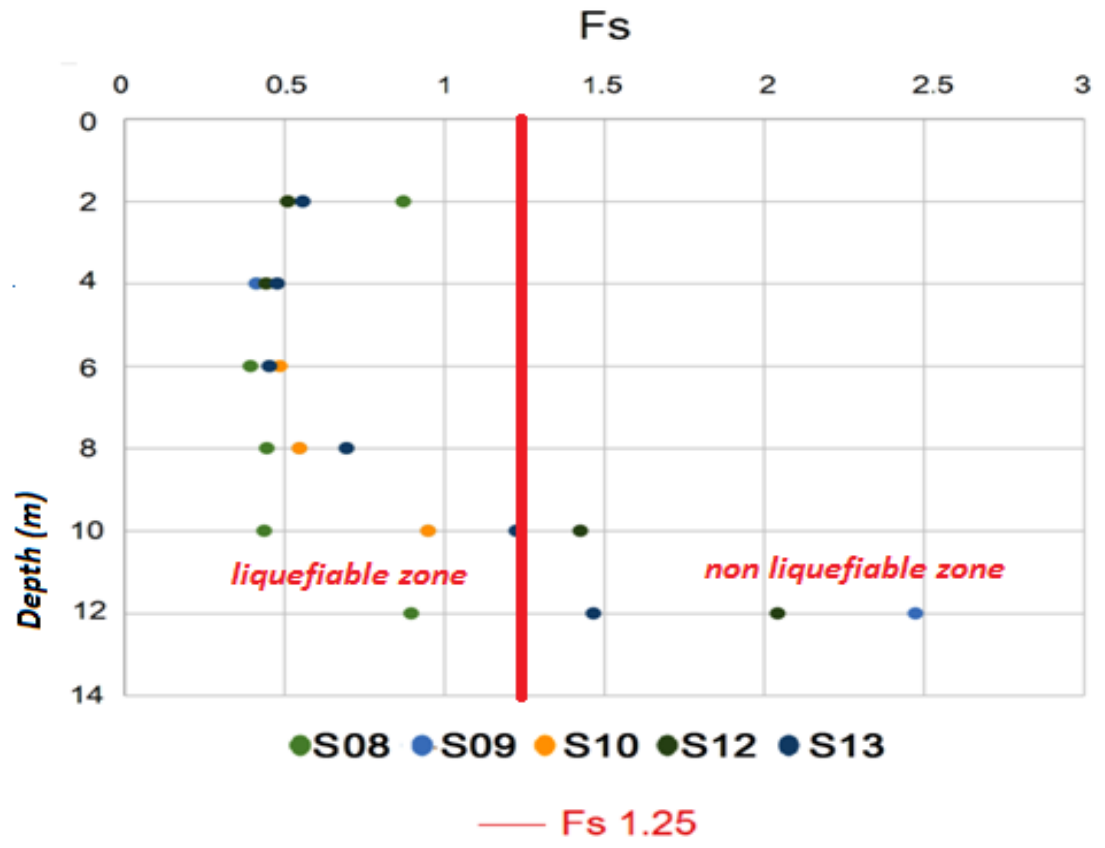

Fig. 7. Variation of Fs with depth

\subsection{Analysis based on CPT tests}

The CRR indices were calculated using the method developed by Robertson and Wride (Robertson and Wride, 1998).

The results obtained (Figure 8) show a risk of liquefaction up to 10 to 12 meters depth, the values of Fs are low and do not exceed the limit (1.25). A modified CPT based method for the liquefaction assessment which is a function of the modified cone bearing and the mean grain size can also be used to predict the cyclic stress ratio $\left(\tau_{1} / \sigma_{\text {vo }}^{\prime}\right)$, (Robertson and Campanella, 1985). 


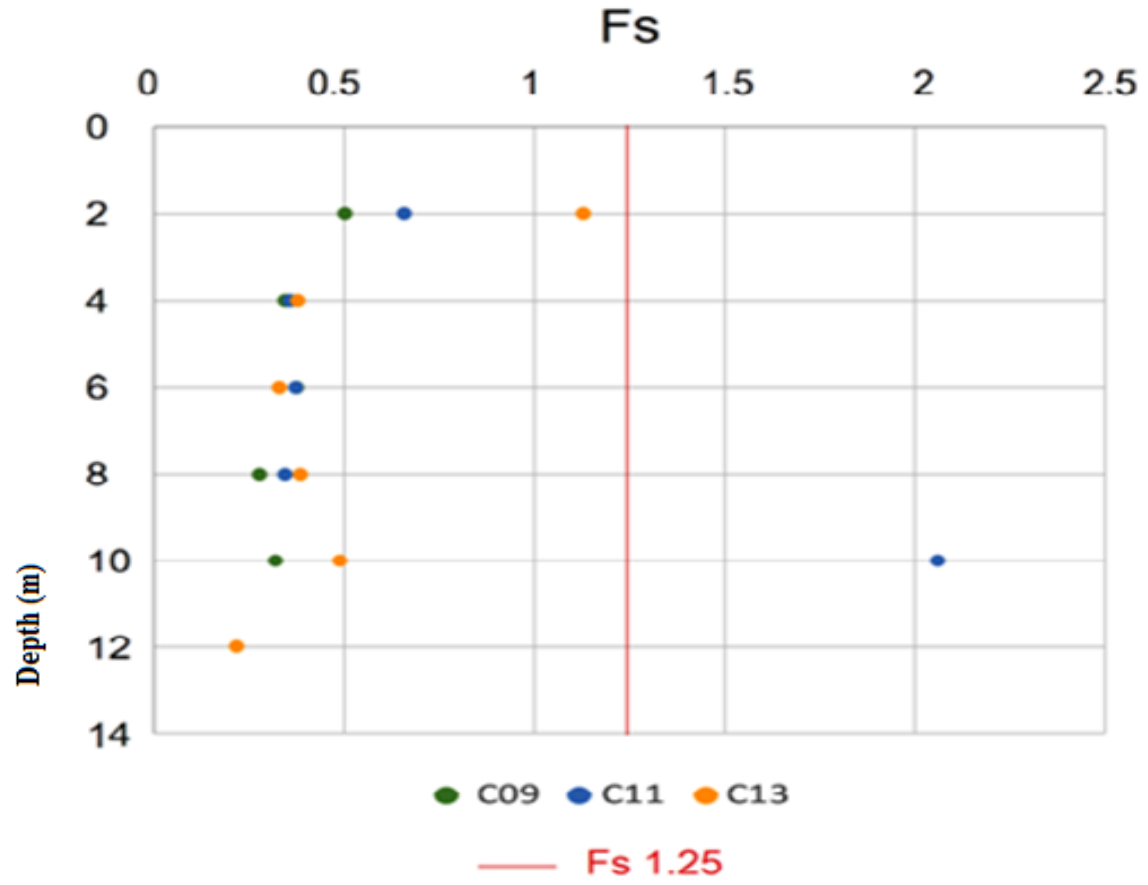

Fig. 8. Variation of Fs with depth

\section{Analysis of liquefaction potential with numerical methods}

SHAKE 2000 software [Ordonez, 2012] was used to calculate the safety factor for liquefaction Fs with the SPT and CPT test data.

\subsection{Comparison based on SPT results}

The results obtained show that the study area is exposed to the risk of liquefaction from the surface up to $10 \mathrm{~m}$ depth.

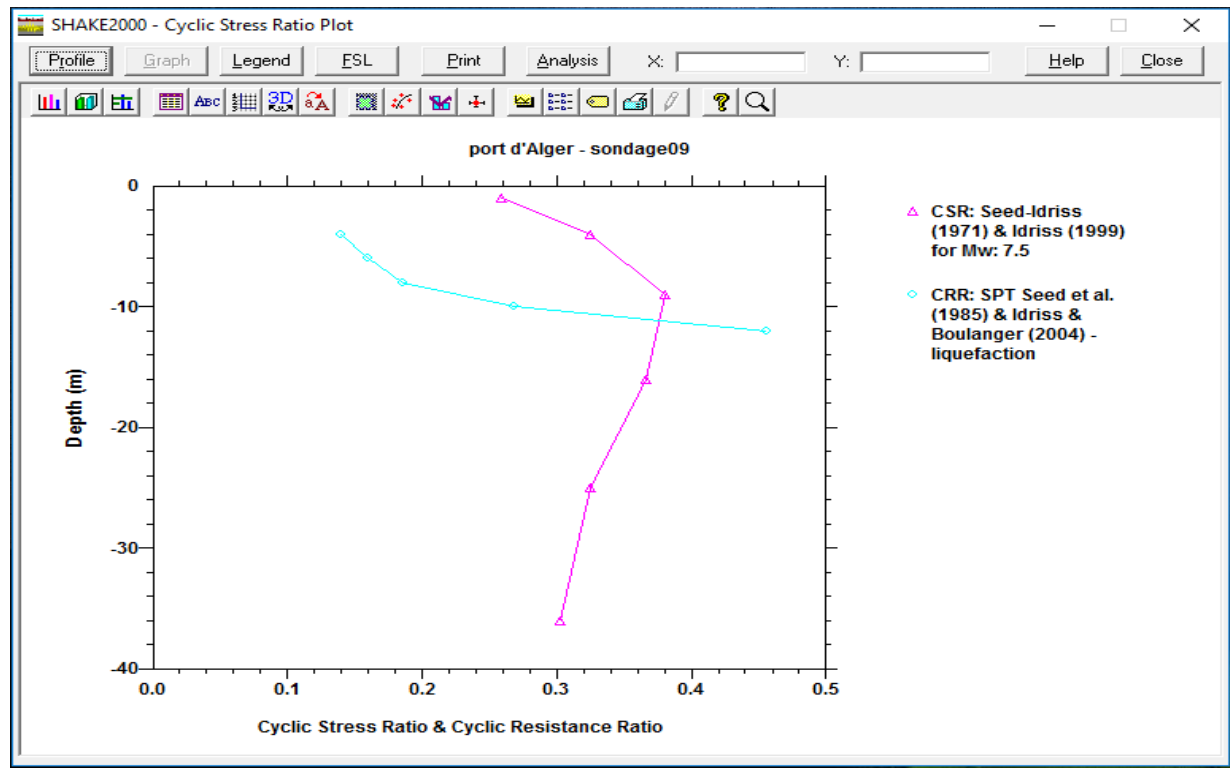

Fig. 9. Variation of CSR and CRR with depth for Borehole S9 


\subsection{Comparison based on CPT tests}

It is clearly shown that the risk of liquefaction is highly probable by both calculation methods, especially in the two zones whose depth varies from 2 to about $12 \mathrm{~m}$.

Through the results obtained, we have shown that empirical results are in accordance with the results obtained by the SHAKE2000 software (Ordonez, 2012).

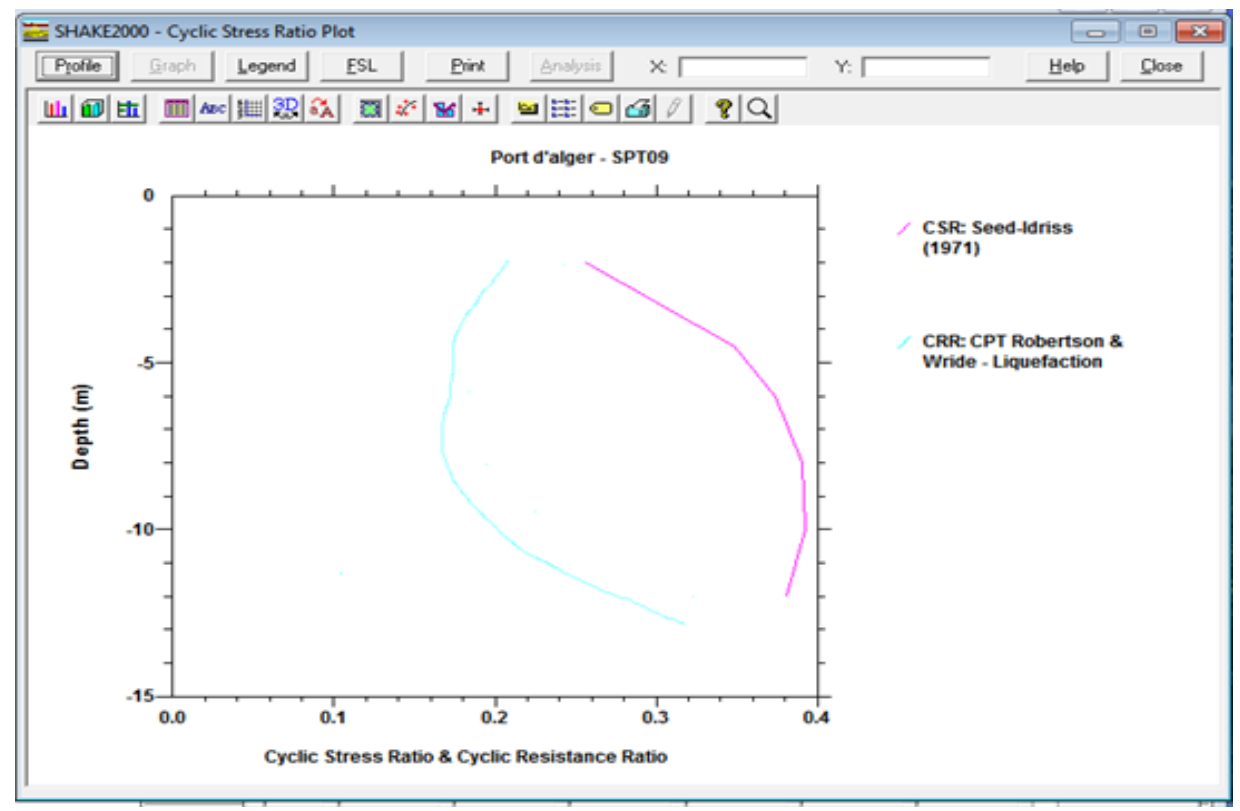

Fig. 10. Variation of CSR and CRR with depth for CPT 13

\section{Simulation}

During the evaluation process, we designed an application by Excel. This application is used to calculate the safety factor Fs, by selecting the method of calculation and the principal values of the data entry $\left(Z, N s p t, q_{c}, \sigma_{v}\right)$. The following flow chart summarizes the operating steps :

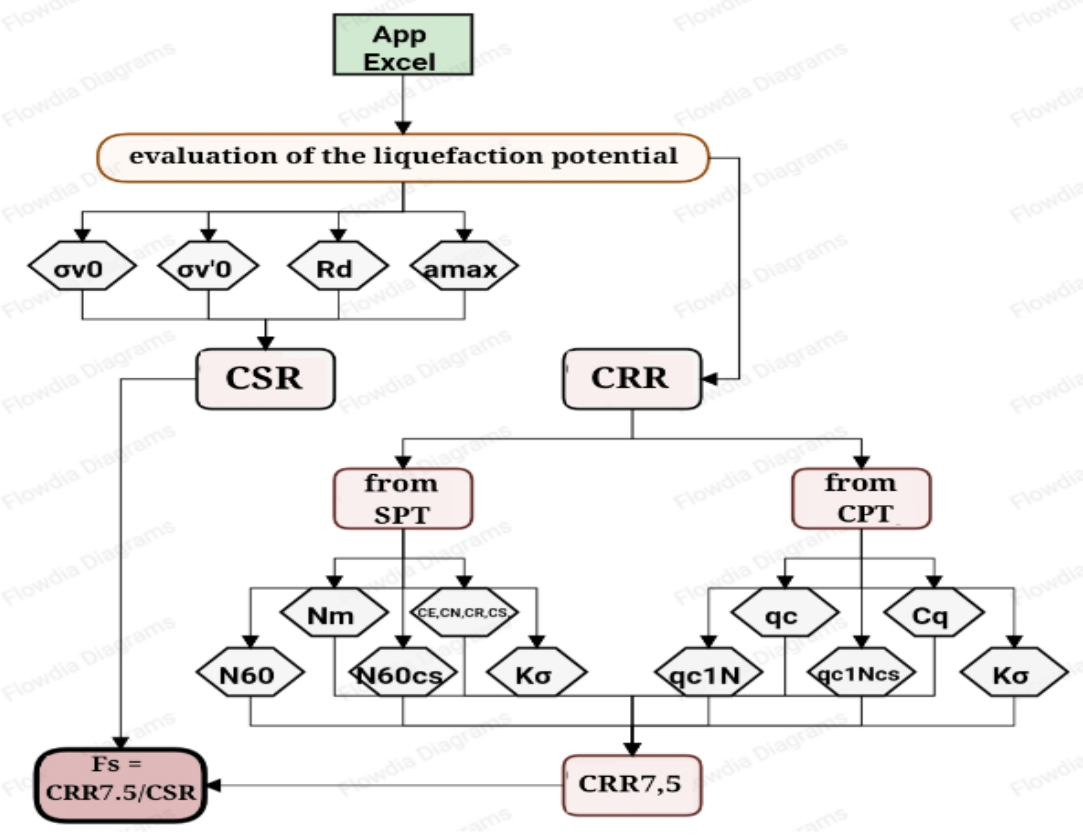

Fig. 11. Operating steps of the application 
Empirical and numerical methods predict liquefaction with similar safety factors.

\section{Stabilization with stone columns}

Stone columns are one of the methods used for stabilizing soft soils. Their use makes it possible to increase the bearing capacity of the soil, reduce its compressibility and also accelerate the consolidation by reducing the drainage path. In addition they have shown that they can reduce the liquefaction potential of the soil during the earthquakes.

Several types of materials exist to form the stone columns such as sand, gravel, fly ash, recycled aggregates, tire chips, etc... (Zukri and Nazir, 2018), some of these applications are still at the research stage but the materials generally used are aggregates.

Despite the widespread use of these columns, current design methods are largely empirical. In what follows we will calculate the diameter and spacing of the columns following 3 simplified approaches, namely Keller's method, static method and dynamic method. Conclusions and recommendations will be developed from the results.

\subsection{Keller's method (CFMS, 2011)}

The method used by Keller is based on experience and site testing and control. Keller installed the stone columns using the wet method to a depth of 7 to $12 \mathrm{~m}$. A diameter of $80 \mathrm{~cm}$ of the columns was chosen with a triangular mesh. The implantation of the columns is hexagonal with a desired substitution rate of $18.7 \%$.

A total of six (6) test zones were made in the site to define the final conditions of implementation in order to achieve the expected results. The positions of the test are shown in Figure 12.

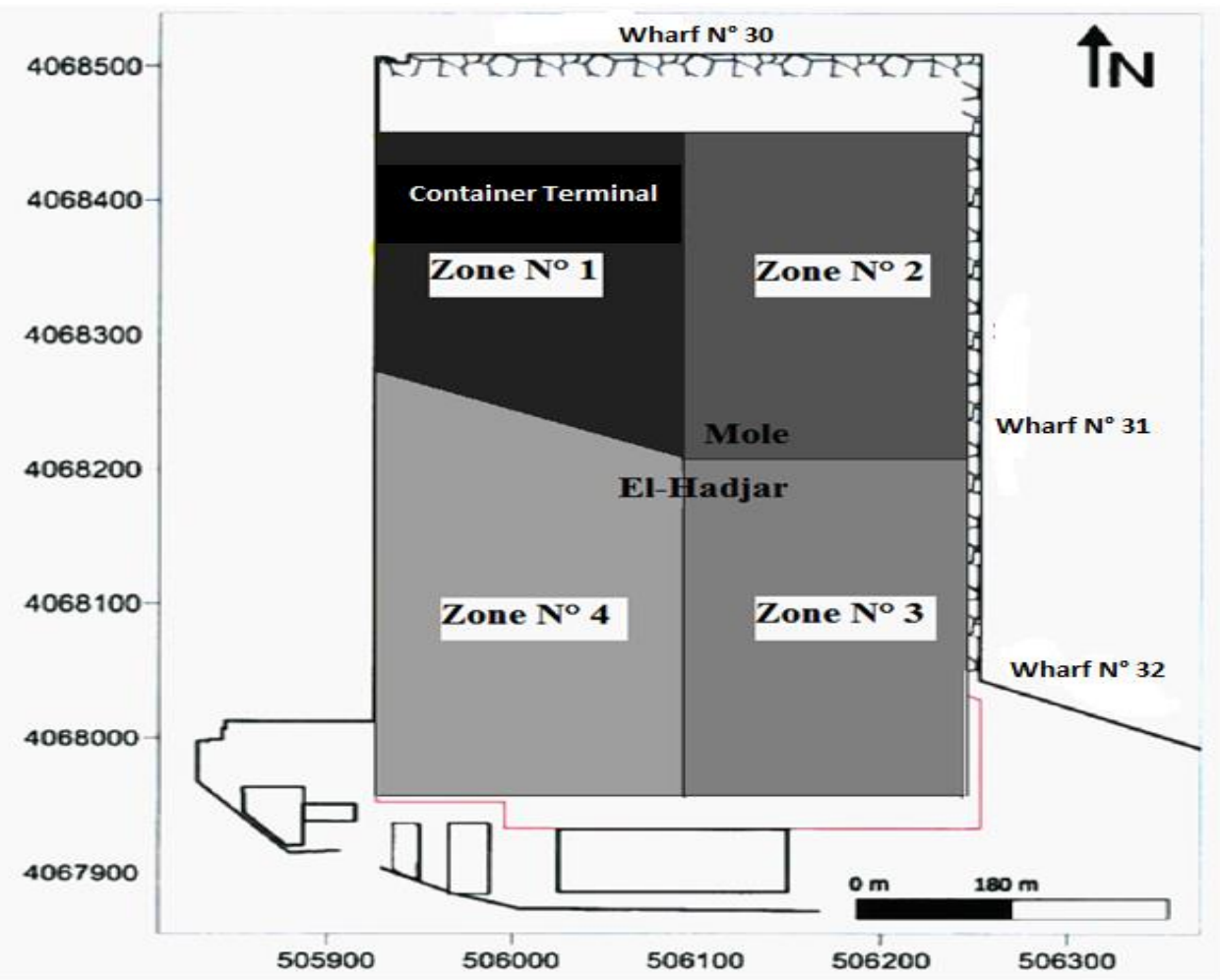

Fig. 12. Location of test benches in the areas to be stabilized 


\subsubsection{Control during installation}

\section{a) Control of materiel supplied}

The constituent material of the stone columns comes from the quarry of El M'hir (Bordj Bou Arreridj). The control is done by laboratory tests to confirm the criteria of the CFMS (2011) and the results are as follows:

Table 1. Results of tests realized in the laboratory on the ballast

\begin{tabular}{|c|c|c|}
\hline Tests & Granular class & Results \\
\hline \hline Wet Microdeval (\%) & $25-50$ & $5.25 \%$ \\
\hline Los Angles (\%) & $25-50$ & $30.56 \%$ \\
\hline Flatness coefficient (\%) & $25-50$ & $0.93 \%$ \\
\hline
\end{tabular}

These values meet the recommendation criteria of the CFMS (2011).

\section{b) System execution parameters (diameter, depth)}

From the volumes of gravel introduced, the equivalent diameter obtained in each of the columns is determined. For its determination, a reduction factor of 1.4 on the volume of the materials incorporated is considered to take into account the losses at the execution, as well as the compaction of the material in the column according to the recommendations of the CFMS (2011). The results obtained in the test zones are as follows:

Table 2. Results of control checks in the tests areas

\begin{tabular}{|c|l|l|l|l|l|l|l|l|}
\hline $\begin{array}{l}\text { Area } \\
\text { No }\end{array}$ & $\begin{array}{l}\text { Test } \\
\text { bench 1 }\end{array}$ & $\begin{array}{l}\text { Column } \\
\text { no }\end{array}$ & $\begin{array}{l}\text { Average } \\
\text { depth }(\mathrm{m})\end{array}$ & $\begin{array}{l}\text { Equivalent } \\
\text { average } \\
\text { diameter } \\
(\mathrm{m})\end{array}$ & $\begin{array}{l}\text { Average } \\
\text { volume }\end{array}$ & $\begin{array}{l}\text { Corrected } \\
\text { volume } \\
\left(\mathrm{m}^{3}\right)\end{array}$ & $\begin{array}{l}\text { Spacing } \\
\text { between } \\
\text { axes (m) }\end{array}$ & $\begin{array}{l}\text { Substituti } \\
\text { on rate } \\
(\%)\end{array}$ \\
\hline \hline 4 & 1 & 28 & 7,45 & 0,86 & 5,87 & 4,28 & 1,7 & 18,7 \\
\hline 1 & 2 & 23 & 12,17 & 0,92 & 11,47 & 8,2 & 1,85 & 19,1 \\
\hline 1 & 3 & 27 & 11,84 & 0,92 & 10,5 & 7,5 & 1,85 & 19,1 \\
\hline 2 & 4 & 28 & 13,22 & 0,86 & 11 & 7,5 & 1,85 & 18,7 \\
\hline 3 & 5 & 27 & 8,97 & 0,80 & 6,5 & 4,5 & 1,8 & 18 \\
\hline 2 & 6 & 25 & 12,07 & 0,92 & 11,5 & 8 & 1,85 & 18,7 \\
\hline
\end{tabular}

\subsubsection{Control after treatment}

The controls shown in Figure 13 are performed in the test zones after treatment.

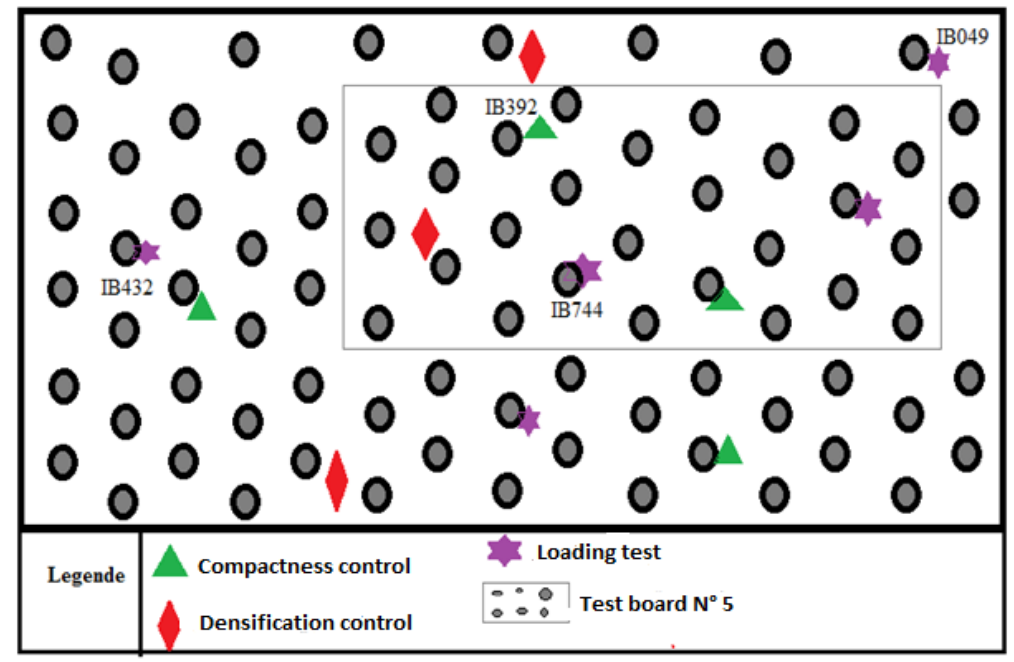

Fig. 13. Location of controls carried out after treatment 


\section{a) Loading tests}

Load tests were performed using 4 comparators. A service load (Qs) was applied on the column, whose value will vary according to the mesh adopted, and it will be necessary to reach a value of $1,5 \mathrm{Qs}$.

The measured settlement curves have shown that column settlements for service loads are generally smaller than $5 \mathrm{~cm}$, which is the permissible limit value (Table 3 ).

Table 3. Loading test results

\begin{tabular}{|c|c|}
\hline Loading tests & 65.9 \\
\hline \hline Load Qs (bars) & 86,40 \\
\hline $\begin{array}{c}\text { Measured } \\
\text { settlement }(\mathrm{cm})\end{array}$ & $0,6-1,58$ \\
\hline
\end{tabular}

\section{b) Control of soil density and column continuity}

The objective of the CPT test between columns is the control of soil densification due to the inclusion of gravel columns, while the test on the columns is for the control of the column continuity and density. Most of the stone columns showed shallow refusal at the top of columns with peak resistances greater than $10 \mathrm{MPa}$.

The results obtained from CPT tests between columns before and after treatment were compared and a marked improvement of the resistance at the tip (Figure 14) was obtained.

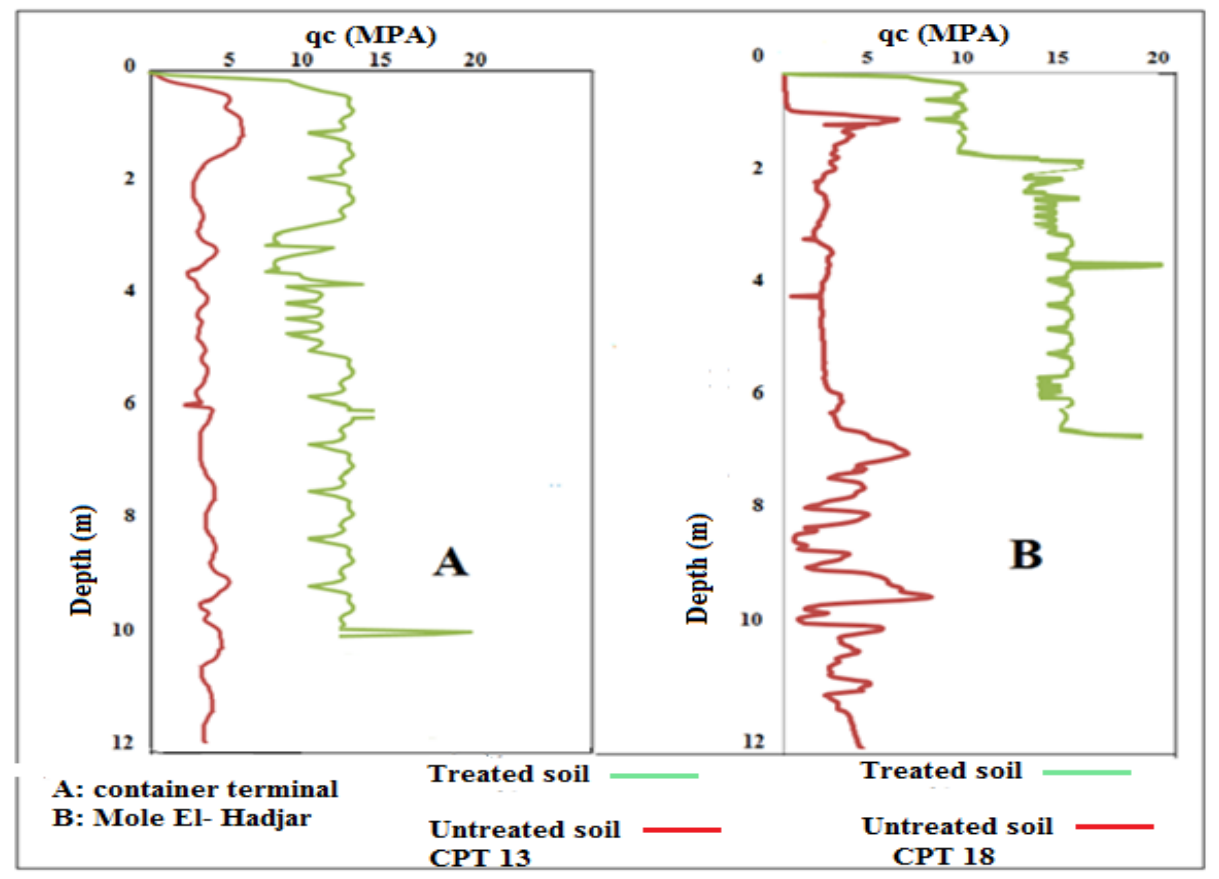

Fig. 14. Variation of qc with depth - Comparison between treated and untreated soils

\subsection{Analysis with static method (Balaam and Booker, 1981)}

The container terminal area has been divided into four areas (Figure 13). In our case the construction of the columns is supposed to be by the wet method and a column diameter of $80 \mathrm{~cm}$ was assumed.

The substitution rate is given by:

$$
\mathrm{a}=\Delta \operatorname{Dr}(\%)=\operatorname{Dr}_{2}-\operatorname{Dr}_{1}
$$


According to the results of the CPT test, the curves show an average value of qc of the order of $2.5 \mathrm{MPa}$, with an average effective stress of $100 \mathrm{kPa}$ on the entire container terminal.

Table 4. Results of relative densities

\begin{tabular}{|c|c|c|c|}
\hline $\begin{array}{l}\text { qc average } \\
(\mathrm{MPa})\end{array}$ & $\begin{array}{l}\sigma^{\prime} \text { v average } \\
(\mathrm{kPa})\end{array}$ & $\mathrm{D}_{\mathrm{r} 1}(\%)$ & $\begin{array}{l}\text { Substitution } \\
\text { rate }\end{array}$ \\
\hline \hline 2,5 & 100 & 20 & 20 \\
\hline
\end{tabular}

Relative densities indicate that the embankment material is loose. Since we want to obtain a relative density Dr2 $=40 \%$ for the material to become compact, the desired substitution rate is given in Table 4.

Table 5. Results of stone column analysis in the areas 1, 2, 3 and 4 with static method

\begin{tabular}{|c|c|c|c|c|c|c|c|c|c|c|}
\hline Area & Mesh & $\begin{array}{c}\mathrm{a} \\
(\%)\end{array}$ & $\begin{array}{c}\varnothing \\
(\mathrm{m})\end{array}$ & $\begin{array}{c}\text { Ac } \\
(\mathrm{m} 2)\end{array}$ & $\begin{array}{c}\text { Am } \\
(\mathrm{m} 2)\end{array}$ & $\begin{array}{c}\mathrm{E} \\
(\mathrm{m})\end{array}$ & $\begin{array}{c}\text { De } \\
(\mathrm{m})\end{array}$ & $\begin{array}{c}\text { Total } \\
\text { surface } \\
\left(\mathrm{m}^{2}\right)\end{array}$ & $\begin{array}{c}\text { Column } \\
\text { no }\end{array}$ & $\begin{array}{c}\text { Depth } \\
(\mathrm{m})\end{array}$ \\
\hline 1 & Triangular & 20 & 0,8 & 0,5 & 2,5 & 2,41 & 2,53 & 35625 & 14250 & 12 \\
\hline 2 & Triangular & 15 & 0,8 & 0,5 & 3,35 & 2,78 & 2,92 & 27500 & 8209 & 12 \\
\hline 3 & Triangular & 15 & 0,8 & 0,5 & 3,35 & 2,78 & 2,92 & 19000 & 5672 & 10 \\
\hline 4 & Triangular & 15 & 0,8 & 0,5 & 3,35 & 2,78 & 2,92 & 34125 & 10187 & 8 \\
\hline
\end{tabular}

The arrangement of the columns is shown in the figure below.

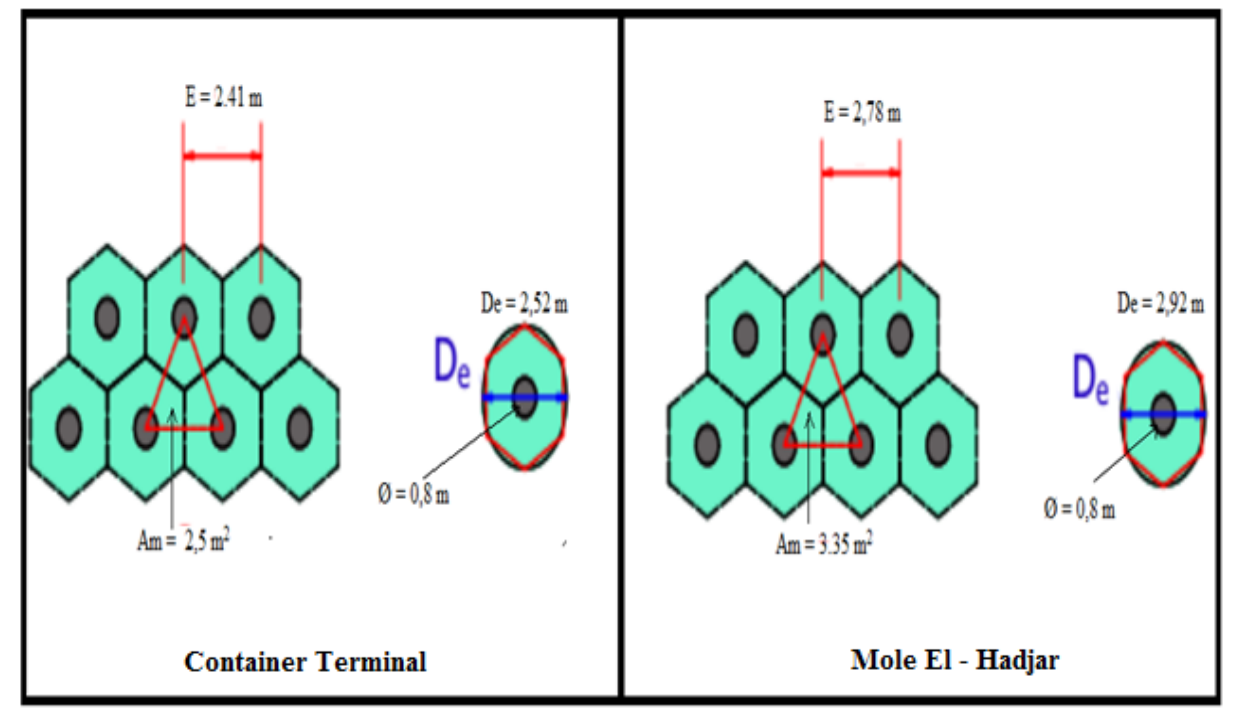

Fig. 15. Stone column details with static method

\subsection{Analysis with dynamic method (Seed and Booker, 1977)}

Data for the Boumerdes earthquake were considered $(\mathrm{Mw}=6.8)$ and therefore the equivalent number of uniform stress (Ns) of 30, the number of cyclic stress application cycles (Ni) of 12 and a duration of the earthquake $(\mathrm{td})$ of $46 \mathrm{~s}$ were assumed.

The properties of the surface layer, namely the coefficient of permeability in the horizontal directions $(\mathrm{Kh})$ of $2.10-5(\mathrm{~m} / \mathrm{s})$, a volume compressibility coefficient $\left(\mathrm{m}_{\mathrm{v} 3}\right)$ of $3.105\left(\mathrm{~m}^{2} / \mathrm{KN}\right)$ and an average ratio of interstitial pressure of 0.6 were considered. The normalized time factor $\left(\mathrm{T}_{\mathrm{ad}}\right)$ is:

$$
\mathrm{T}_{\mathrm{ad}}=\frac{K h}{\gamma_{w}} \cdot \frac{t_{d}}{m_{v 3} \cdot r d^{2}}
$$

After calculation, we get $\mathrm{T}_{\mathrm{ad}}=19.54$ 
For Ns $/ \mathrm{Ni}=2.5$, we obtain $\mathrm{Rd} / \mathrm{Re}=0.27$, with Rd: Radius of the column. Re: Spacing between the columns. As a column diameter of $0.8 \mathrm{~m}$ was chosen, a mean Re of $1.5 \mathrm{~m}$ can be adopted (Figure 16).

Table 6. Results of stone column analysis in the areas 1, 2, 3 and 4 with dynamic method

\begin{tabular}{|c|l|l|l|l|l|l|l|c|}
\hline Area & Mesh & $\begin{array}{l}\emptyset \\
(\mathrm{m})\end{array}$ & $\begin{array}{l}\mathrm{Ac} \\
\left(\mathrm{m}^{2}\right)\end{array}$ & $\begin{array}{l}\mathrm{Am} \\
\left(\mathrm{m}^{2}\right)\end{array}$ & $\begin{array}{l}\text { Re } \\
(\mathrm{m})\end{array}$ & $\begin{array}{l}\text { Total } \\
\text { surface } \\
\left(\mathrm{m}^{2}\right)\end{array}$ & $\begin{array}{l}\text { Column } \\
\text { no }\end{array}$ & $\begin{array}{l}\text { Depth } \\
(\mathrm{m})\end{array}$ \\
\hline \hline 1 & Triangular & 0,8 & 0,5 & 0,97 & 1,5 & 35625 & 36727 & 12 \\
\hline 2 & Triangular & 0,8 & 0,5 & 0,97 & 1,5 & 27500 & 28351 & 12 \\
\hline 3 & Triangular & 0,8 & 0,5 & 0,97 & 1,5 & 19000 & 19588 & 10 \\
\hline 4 & Triangular & 0,8 & 0,5 & 0,97 & 1,5 & 34125 & 35180 & 8 \\
\hline
\end{tabular}

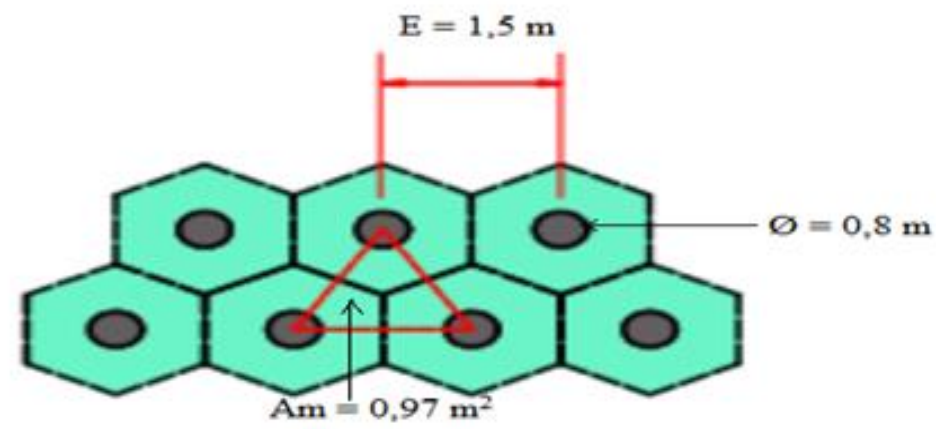

Fig. 16. Stone column details with dynamic method

\section{Comparison between the results}

The results showed that the spacing between the columns obtained by Keller's method and the static method is higher than the spacing obtained by the dynamic method. As a result, the number of columns obtained by the dynamic method is greater. This is predictable because the dynamic method takes into account the seismic loading. This highlights the error made by certain companies that uses observational techniques to design stone columns in areas at risk of liquefaction. In such areas dynamic method are required.

The above results are based on simple empirical analysis methods and need to be confirmed by methods based either on small scale models and/or develop numerical models that take into account the heterogeneity of materials, dissipation of interstitial pressures and dynamic stresses.

\section{Conclusions}

Diameter and spacing of stone columns were assessed using 3 methods and it was noticed a difference between the results.

The method used by Keller is mainly observational. It clearly showed that the soil was improved and compacted based on post-treatment trials. However it has been used to reduce the settlement problem only while the soil has been confirmed to be potentially liquefiable as well.

The results of the 3 methods have shown that if we size by taking into account the dynamic solicitations, the mesh of stone columns is denser. Therefore it is recommended to analyze by the dynamic method in seismic zones and by static or observational techniques in areas of low or no risk of liquefaction.

However, it is useful that stabilization results be confirmed by methods based on small scale models to verify the findings of the empirical dynamic method. 


\section{References}

Babu, M. D., Nayak, S., \& Shivashankar, R. (2013). A critical review of construction, analysis and behaviour of stone columns. Geotechnical and Geological Engineering, 31(1), 1-22.

Balaam, N. P., \& Booker, J. R. (1981). Analysis of rigid rafts supported by granular piles. International journal for numerical and analytical methods in geomechanics, 5(4), 379-403.

Blake, T. F. (1997). Summary Report of Proceedings of the NCEER Workshop on Evaluation of Liquefaction Resistance of Soils. Youd TL, and Idriss IM. eds., Technical Report NCEER 97-0022.

CFMS, (2011). Recommandations sur la conception, le calcul, l'exécution et le contrôle des colonnes ballastées sous bâtiments et sous ouvrages sensibles au tassement, Comité Français de Mécanique des Sols.

Faccioli, E., \& Resendiz, D. (1976). Soil dynamics behavior including liquefaction in seismic risk and engineering decisions, Lomnitz and Rosenblueth, Eds, Elsevier Scientiific publishing co. , New York, pp. 71-140, chap 4.

Han, J., \& Ye, S. L. (2002). A theoretical solution for consolidation rates of stone column-reinforced foundations accounting for smear and well resistance effects. International Journal of Geomechanics, 2(2), 135-151.

Idriss, I. M., \& Boulanger, R. W. (2006). Semi-empirical procedures for evaluating liquefaction potential during earthquakes. Soil dynamics and earthquake engineering, 26(2-4), 115-130.

Kumari, S., Sawant, V. A., \& Mehndiratta, S. (2018). Effectiveness of Stone Column in Liquefaction Mitigation. Proceedings of Geotechnical Earthquake Engineering and Soil Dynamics V. 207-216.

Ordóñez, G. A. (2012). SHAKE2000: A Computer Program for the 1-D Analysis of Geotechnical Earthquake Engineering Problems. GeoMotions, LLC, Lacey, Washington, USA.

Robertson, P. K., \& Campanella, R. G. (1985). Liquefaction potential of sands using the CPT. Journal of geotechnical engineering, 111(3), 384-403.

Robertson, P. K., \& Wride, C. E. (1998). Evaluating cyclic liquefaction potential using the cone penetration test. Canadian geotechnical journal, 35(3), 442-459.

RPA99 (2003), Règles Parasismiques Algériennes, Centre national de recherché appliqué en génie parasismique.

Samuel Thanaraj M., Freeda Christy C., Brema J. (2019). Analysis on the Performance of Stone Columns with Different Materials in Soil Stabilization, International Journal of Engineering and Advanced Technology (IJEAT), 8(3S), 148-153.

Sarker, D., \& Abedin, M. Z. A Review on Ground Improvement Techniques to Improve Soil Stability against Liquefaction., International Journal of Science and Engineering Investigations, 4(40):53-55.

Seed, H. B. \& Idriss, I. M. (1971). Simplified procedure for evaluating soil liquefaction potential, Journal of Soil Mechanics and Foundation Division, ASCE, Vol. 107, No SM9, 1249-1274.

Seed, H. B., \& Booker, J. R. (1977). Stabilization of potentially liquefiable sand deposits using gravel drains, Journal of the Geotechnical Engineering Division, ASCE, Vol. 103, No. GT7, 757-768.

Zukri, A., \& Nazir, R. (2018). Sustainable materials used as stone column filler: A short review. In IOP Conference Series: Materials Science and Engineering, Vol. 342, No. 1, p. 012001. IOP Publishing. 